\title{
Research on Improvement of College Students' Trust in Counselors under the Guidance of "Five Development Concepts"
}

\author{
Dawei Qin \\ Chengdu Normal University \\ Chengdu, China
}

\begin{abstract}
Students' trust in counselor is an important guarantee for effective work of counselors, strengthening the effects and making it easier for ideological and political education. "Five Development Concepts" proposed on the Fifth Plenary Session of the 18th Central Committee of the Communist Party of China provides scientific theoretical guidance to improve the trust relationship between teachers and students. In the improvement of trust in counselors, we should take innovative development as the guidance to innovate in the thoughts and methods; take coordinated development as the link to build new platform; take green development as the power to create new quality; take the open development as the means to supplement new paths; take shared development as the support to lay solid foundation.
\end{abstract}

\section{Keywords-“five development concepts"; counselor; trust}

\section{INTRODUCTION}

College counselors play the roles of teacher and administrator, referring to the important organizer and implementer of ideological and political education and daily management of college students. As the front line teachers, counselors carry out ideological and political education on students, help students to establish correct world outlook, outlook on life and values and ensure the reasonable and effective implementation of student work, in order to realize the safe, steady and integrated development of students. The trust relationship between counselors and students contributes to the ideological and political education and student management. Therefore, it is of vital importance to improve the trust relationship between students and counselors in order to fulfill the education and management effectively.

Counselors need new theory as the guidance under new situation. Our country pays special attention to theoretical development and innovation. It proposes on the Fifth Plenary Session of the 18th Central Committee of the Communist Party of China that we must firmly establish the innovative, coordinated, green, open and shared development concepts, in order to achieve the development goal of the "13th Five-year" period, solve development problems and strengthen the development strengths. The five development concepts are powerful guidance to solve complicated problems under the economic new normal and the guiding thought to improve the trust relationship between counselors and students. Counselors should be guided by five development concepts to strengthen the trust relationship between teachers and students, and then strengthen the effectiveness of ideological and political education on college students, realize the harmony and stability of campus and the growth of students.

II. TAKE INNOVATIVE DEVELOPMENT AS THE GUIDANCE TO INNOVATE IN THOUGHTS AND METHODS IN IMPROVEMENT OF TRUST IN COUNSELORS

Five development concepts are proposed on the Fifth Plenary Session of the 18th Central Committee of the CPC with innovative development as the core. Innovation is the soul in the progress of a nation, the inexhaustible impetus of national prosperity. The proposition of mass entrepreneurship and innovation and innovative development idea indicates innovation has become the theme of social development nowadays, the core idea to run through all work and the powerful ideological guidance to strengthen the trust relationship between counselors and college students.

First, innovate in new thoughts in improvement of trust in counselors. Nowadays, college students are born after 1995 . They have independent consciousness and acquire diversified knowledge systems through application of media. Compared with college students in the past, they have opinions, ideas and personality of their own, making them more active and mature. Meanwhile, they have weak consciousness of responsibility, weak group consciousness, absence of political accomplishment and distorted values. It makes ideological and political education on students and student management more difficult. If counselors still follow the previous ways of education or management, it will influence the effectiveness of education and management and impede the construction of trust relationship between teachers and students. Therefore, under new situation, counselors should adapt to the environment, take the initiative to strengthen communication and continuously innovate in thoughts in the previous work experience and practice. Meanwhile, the trust relationship between counselors and college students should be established on the basis of student-oriented teaching idea. The trust relationship can be improved to realize the optimization of educational effects. 
Second, innovate in methods in improvement of trust in counselors. According to the national requirements, the most reasonable proportion of counselor and students in guidance is one to two hundred. But in many colleges, one counselor guide more than two hundred students. Some counselors have teaching tasks and take care of the family, so they spend less time to communicate with students. It makes the student work more difficult and influences the improvement of students' trust in counselors. General Secretary Xi Jinping addresses on the session of the national ideological and political work in colleges, "ideological and political work must center on, care for and serve students, continuously improve students' ideological level, political consciousness, moral character and artistic appreciation to let them become talents with both political integrity and professional competence and integrated development". It requires counselors to center on students and reform working methods to strengthen the trust relationship between teachers and students. Transform passive management into active management and ask for information of students and find implicit problems of students; show love, patience and sense of responsibility for students, take the initiative to help students instead of ignoring; innovate in forms or categories of student activities and strengthen the affective interaction with students through guiding student activities or participating in it; innovate in educational methods, combine the explicit and "duck-stuffing" type of teaching with invisible and interactive educational method with self-education; continuously explore the methods of psychological counseling and intervention for students; learn and apply carriers like media, activities and culture, make counselors integrate in students, so that students can know about counselors and make interaction with them and teachers can know about students more clearly in caring for, guiding, serving and managing students. The student work of counselors becomes benign interaction, which is conducive to improving students' trust in counselors.

\section{TAKE COORDINATED DEVELOPMENT AS THE LINK TO BUILD NEW PLATFORM IN IMPROVEMENT OF TRUST IN COUNSELORS}

"Coordinated development is the intrinsic requirement of sustainable and healthy development." [1] The mutual coordination of elements can promote the reasonable and orderly development the entirety. The establishment and improvement of trust relationship between counselors and college students is the entity formed by multiple factors like subject, object and carrier. These elements have mutual influence, restriction and relationship. The high trust level between teachers and students can make the ideological work on people more effective. However, counselors are responsible for ideological and political education and solve problems of students, implement work tasks of functional departments, maintain students' safety and stability of students in school. Meanwhile, they face problems in personal development, career identity and family. It requires counselors to coordinate these elements and contradictions seriously and orderly in order to build new platform and optimize the trust relationship between college students and counselors.

First, coordinate main channel and main front of ideological and political education. Our country provides ideological and political course for college students, taking ideological and political theory course as the main channel and the daily ideological and political education on college students as the main front. The main channel helps student to know about the national conditions and the history of the Party of our country, improve political accomplishment and establish solid political conviction; the main front helps students to solve problems and guides them to establish correct world outlook, outlook on life and values. The joint implementation of main channel and main front makes the ideological and political work run through the whole process of students' growth to realize all-round education. Counselors are main workers on the main front of ideological and political education. They should coordinate the relationship between main channel and main front instead of depending on the classroom of ideological and political theory course to realize ideological and political education. Furthermore, counselors should integrate in students' life through group learning activities, class meeting and heart-to-heart talk, carry out ideological and political education through communication with students and accurately grasp students' change of thoughts, excluding the difficulty and anxiety of students to gain trust of students.

Second, insist the coordination of fairness and rationality with personal tendency. In student affairs management, counselors influence students' benefits in recommending the excellent to join the Party, deciding on awards through discussion, appraising and selecting the most outstanding, financial support and selection of student cadre. In real work, counselors cannot reach every aspect of matters so they ask some students to assist. In this way, counselors inevitably have personal emotional tendency and give priority to these students. It directly influences the benefits of other students and the image of counselors. The awarding, evaluation and support of students should adhere to the principles of openness, impartiality and fairness. But counselors will disobey the principles because of management requirements or personal emotional tendency, weakening students' trust in counselors and influencing student management. Therefore, counselors must coordinate fairness and rationality with personal tendency, give guidance and help in training student cadre and make them come out top in work and learning. They follow the principles of openness, impartiality and fairness and establish a good image. Students accept the counselors' work and Student cadres set a good example. The effect of ideological and political education is optimized.

Second, insist the coordination of teaching and scientific research with student management. Counselors are important part in teaching body and management team in colleges and play the role of teacher and administrator. In some colleges, counselors are regarded as teachers with management function. In conferring of academic titles, counselors can choose post of professional skill or management post. Nowadays, college counselors have increasingly high education level. Master degree is the starting point. Key universities of 985 Project and 211 Project require counselors to have doctorate. Some even sign the contract of scientific effort. Most counselors with high academic qualifications are unwilling to abandon their specialty so they choose the professional title on post of professional skill. The conferring of academic titles for post of 
professional skill requires the completion of teaching tasks and scientific payoffs. Counselors take change of student work at the same time. The time allocation on teaching and scientific research and student management is unequal. Some counselors pay attention teaching and scientific research and muddle through the student work, neglect problems of students, becoming alienated from students. It is difficult to establish trust relationship. Therefore, counselors must coordinate the relationship between teaching and scientific research with student management. The core of work of counselors is student work. Teaching and scientific research comes from real life. When organizing and leading students to visit, practice, provide voluntary service and take activities of going to the countryside to spread scientific and literacy knowledge and offer medical service to farmers, relieve poverty and support education, counselors also have opportunities to walk out of the campus and know about the reality. It provides new materials or breakthrough points for their teaching and scientific research. Meanwhile, more opportunities are provided for counselors and students to communicate, making for the establishment of trust relationship.

\section{TAKE GREEN DEVELOPMENT AS THE POWER TO CREATE NEW QUALITY IN IMPROVEMENT OF TRUST IN COUNSELORS}

Green development concept is the intrinsic requirement and inevitable choice to realize sustainable development of society. Nowadays, green has become a value representing ecology, efficiency, harmony and sustainability. Green is a work concept and guides us to follow students' development law and respect their growth law in education and teach students in accordance of their aptitude. The students' trust in counselors is not established in a day. Counselors must depend on the green development to continuously reflect on and improve themselves to improve emotional appeal and affinity, win students' respect and support and create the green quality of college students' trust in them.

First, strengthen self-cultivation. Green development represents sustainable development, requiring counselors to learn, make progress and strengthen self-cultivation unremittingly. Self-cultivation of counselors is the key to improve students' trust in them. Counselors mainly do student work. These students born after 1995 have strong selfawareness. They have active mind and rich emotions. Counselors must have high self-cultivation to win students' respect and admiration as well as trust. In ideological and political education on college students, counselors must have firm political stand and correct world outlook, outlook on life and values, quick mind and extensive knowledge, helping students to solve ideological problems and leading their ideology. As administrators of students, counselors should keep pace with the times, teach by personal example as well as verbal instruction and learn knowledge of pedagogy, educational psychology, organizational behavior and management. At the meantime, they can actively pay attention to Official Accounts to learn and improve skills, update knowledge reserve system and bring scientific management concept in work, in order to improve work efficiency, scientifically and reasonably help students to solve problems and become the person knowing something of everything and everything of something.

Second, set a good example for students. Dedication to work is not only the requirement of socialist core values but also the requirement of code of professional ethics for college teachers. Therefore, counselors must cherish posts and devote wholeheartedly to work, becoming enthusiastic in work to carry out students' integrated development. Counselors care for students with chariness and responsibility to imperceptibly guide students become positive and acquire their respect and admiration. On the contrary, if counselors muddle along, it will go against students' growth and make students fed up with them, impeding the establishment of trust relationship between teachers and students.

Third, treat students with loving heart. Only loving heart can make counselors truly care for students and help students to solve problems. Counselors with loving heart have enthusiasm in student work, take the initiative to think about and solve problems of students. They dare to take responsibility and face difficulties. Loving heart makes counselors get along with students harmoniously. The casual supportive expression in eyes of counselors and their concerned words are expressions of love, move students and win trust. Counselors' dedication of love makes the relationship between them and students more intimate and accumulate the trust relationship.

\section{TAKE THE OPEN DEVElopment as the MEANS to SUPPLEMENT NEW PATHS IN IMPROVEMENT OF STUDENTS' TRUST IN COUNSELORS}

Counselors must insist the open development concept and learn advanced knowledge, experience and technology to broad horizon. Students' trust in counselors not only simplifies counselors' work but also strengthen the effectiveness of ideological and political education. Therefore, counselors should use opener concept to develop the trust relationship between teachers and students, use open mind, open work environment, open horizon and emotions to supplement new paths in order to strengthen the trust relationship between teachers and students.

First, counselors have open mind. In ideological and political education on students, counselors should have a peaceful state of mind and become tolerant. A tolerant teacher shows high quality and wisdom. Tolerance is the requirement of education and the key to trust relationship between teachers and students. College students have stronger sense of independence. They dare to think and dare to do and challenge, and show personality with great potential of creative power. Nobody's perfect. Students will make mistakes and need a tolerant counselor to guide them in correcting mistakes instead of severely criticizing, punishing and suppressing them. When students make mistakes, a counselor with an open mind first think how to help students solve problems and guide them to be positive. In the process of growth, they create opportunities for students to express themselves according to students' characteristics. Meanwhile, they are considerate to let students feel warm and tolerance. Counselors should not think students trouble them and hold the grudge. An open mind is an 
important opportunity for counselors and students to establish trust relationship. It does not mean making endless concession but tolerate students when guiding students to realize and correct mistakes, in order to make students gain experience and grow better.

Second, the work environment of counselors is open. With the soaring development of science and technology and the penetration of information technology, the era of big data and "Internet Plus" with network as the carrier has come. Network is inseparable from our life in teaching, work, life, leisure, and entertainment and shopping. Student group has depended on network life and can be called as the main force of network. Therefore, counselors should not confine to traditional work environment like office, classroom and dormitory. Instead, they should face the network and open the work environment to carry out ideological and political education and exert influence in the network environment and build new-type relations between students and teachers. Counselors grasp students' change of thoughts through Official Accounts, bbs, weibo, WeChat and QQ as well as we media. They can integrate in students' life space, establish the second work platform and open the work environment online and offline, creating good environment for the trust relationship between teachers and students.

Third, counselors must have an open horizon. With the social development, the impact of diversified thoughts and the collision of values, counselors will encounter troublesome difficulties in student work. The misconduct will make counselors lose prestige. Counselors must have broad horizon, use the concept of going out and bringing in, seek advice from colleagues and predecessors as well as learn experience of student work at home and abroad, in order to complete student work, improve students' trust in them instead of making no effort to seek progress.

\section{TAKE SHARED DEVELOPMENT AS THE SUPPORT TO LAY SOLID FOUNDATION IN IMPROVEMENT OF STUDENTS' TRUST IN COUNSELORS}

"The core idea of shared development is everyone's participation, dedication and enjoyment, in order to let all members of society equally participate in social activities and enjoy achievements of it." [2] The shared development concept means counselors must seize the core elements, stick to the student-oriented principle to realize the integrated development of college students. Moreover, it is necessary to treat students equally, share educational achievements, make progress together and bring humanistic care in students' learning, life and work, laying a solid foundation for college students' trust in counselors through interaction with students, the participation of students and sharing of achievements.

First, drive the sharing of educational achievements through mutual improvement. The basic task of colleges is education. It requires students to participate, receive education and share educational achievements. In this process, counselors must carry out ideological and political education and provide guidance for students' problems in learning, career planning and vocational counsel. The era develops continuously and knowledge will not invariable. "Students' trust in teachers will reduce if teachers fail to research professional knowledge." [3] If counselors are caught in affairs instead of learning learn new knowledge, they will be unable to give corresponding guidance to students. It will lower the recognition degree of students toward counselors and influence improvement of trust relationship between teachers and students. Therefore, counselors must be adept in arranging time reasonably, dealing with affairs at the same time unremittingly updating knowledge reserve to guide students. It will benefit both teachers and students who share educational achievements and make progress. Meanwhile, the trust relationship between teachers and students will be strengthened.

Second, drive educational equality and sharing through humanistic care. "Ideological and political education in colleges should base on college students' practical need and combine education with guidance, respect, understanding and care, in order to maintain and realize the fundamental interests of college students." [4] As the front line ideological and political educators, counselors should care for, respect and treat students equally, maintain their fundamental interests. Humanistic care is an indispensable requirement. Although the school records of students differ, educational resources should not be distributed to students unequally. As the bridge between teachers and students, counselors should neither say turkey to one and buzzard to another nor distribute educational resources equally, because it goes against students' development, violates educational concepts and makes students complain about counselors so the trust will not be established. Counselors should care for students sincerely, identify the career and respect students, distributing educational resources to every student. It will lay a solid foundation for the establishment of college students' trust in counselors.

\section{REFERENCES}

[1] Liu Jun. Promote New Development of Ideological and Political Education in Colleges through Five Development Concepts [J], Shandong Trade Unions' Tribune, 2016 (10)

[2] Wang Gang. Lead Ideological and Political Education in Colleges through "Five Development Concepts" [J], Studies in Ideological Education, 2016 (7)

[3] Wang Qin. Research on Trust Relationship between College Counselors and Students [D], Chengdu: Southwestern University of Finance and Economics, 2012

[4] Wang Gang. Lead Ideological and Political Education in Colleges through "Five Development Concepts" [J], Studies in Ideological Education, 2016 (7) 